\title{
Performance of the EuroSCORE II and the STS score for cardiac surgery in octogenarians
}

\author{
EUrOSCORE II ve STS skorlarının 80 yaş ve üzeri kalp cerrahisi hastalarında performansı
}

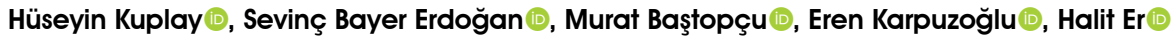 \\ Department of Cardiovascular Surgery, Dr. Siyami Ersek Thoracic and Cardiovascular Surgery Training and Research Hospital, Istanbul, Turkey
}

\begin{abstract}
Background: We aimed to investigate the predictive value of Society of Thoracic Surgeons (STS) and European System for Cardiac Operative Risk Evaluation (EuroSCORE II) scores for mortality in octogenarian cardiac surgery patients.

Methods: Between January 2016 and December 2019, cardiac operations performed in 116 octogenarian patients (73 males, 43 females; mean age: $82.9 \pm 3.1$ years; range, 80 to 97 years) were retrospectively analyzed. The patients with and without mortality were compared for their demographic and operative factors. The STS and EuroSCORE II scores, and observed mortality rates were assessed.

Results: Mean STS score was $3.7 \pm 11.1$ and mean EuroSCORE II was $5.2 \pm 5.4$. For any operation type, the mean EuroSCORE II was significantly higher $(8.1 \pm 7.4$ vs. $4.1 \pm 4.0$, respectively; $\mathrm{p}=0.006)$ in the patients with mortality. For elective operations, the mean EuroSCORE II was higher in cases with mortality $(7.2 \pm 7.3 \mathrm{vs}$. $3.7 \pm 3.9$, respectively; $\mathrm{p}=0.006$ ); however, for urgent cases, there was no significant difference between the scores. Using the receiver operating characteristic curve, the EuroSCORE II had a higher area under the curve for all cases and elective cases than the STS scores.

Conclusion: The EuroSCORE II performed better than the STS score for mortality prediction in octogenarians, whereas the predictions of either scoring system was unsatisfactory for urgent surgery and combined procedures. Population-based validation studies are needed for a better risk scoring system in this age group. Keywords: Cardiac surgery, mortality, octogenarian, risk scores.
\end{abstract}

\section{$\ddot{O} Z$}

Amaç: Bu çalışmada Göğüs Cerrahisi Derneği (STS) ve Avrupa Kardiyak Operatif Risk Değerlendirme Sistemi II (EuroSCORE II) skorlarının 80 yaş ve üzeri kalp cerrahisi hastalarında mortalite için öngördürücü değeri araştırıldı.

Çalışma planı: Ocak 2016 - Aralık 2019 tarihleri arasında 80 yaş ve üzeri 116 hastada (73 erkek, 43 kadın; ort. yaş: 82.9 \pm 3.1 yıl; dağılım, 80-97 yıl) gerçekleştirilen kalp ameliyatları retrospektif olarak incelendi. Mortalite görülen ve görülmeyen hastalar demografik ve cerrahi faktörler açısından karşılaştırıldı. STS, EuroSCORE II skorları ve gözlenen mortalite oranları karşılaştırıldı.

Bulgular: Ortalama STS skoru $3.7 \pm 11.1$ ve ortalama EuroSCORE II 5.2 \pm 5.4 idi. Tüm cerrahi türlerinde, ortalama EuroSCORE II mortalite gözlenen hastalarda daha yüksekti (sırasıyla, 4.1 \pm 4.0 'e kıyasla 8.1 $\pm 7.4 ; \mathrm{p}=0.006$ ). Elektif cerrahilerde ortalama EuroSCORE II mortalite görülen olgularda daha yüksekti (sırasıyla, 3.7 \pm 3.9 'a kıyasla 7.2 $\pm 7.3 ; \mathrm{p}=0.006$ ); ancak, acil olgularda skorlar arasında bir fark gözlenmedi. Alıcı işletim karakteristik eğrisi ile STS skorlarına kıyasla, EuroSCORE II'nin eğri altında kalan alanı tüm olgularda ve elektif olgularda daha yüksekti.

Sonuç: EuroSCORE II 80 yaş ve üzeri hastalarda STS skoruna kıyasla mortaliteyi öngörmede daha iyi bir performans gösterirken, acil cerrahiler ve kombine işlemlerde iki skorlama sisteminin öngördürücülüğü yetersizdi. $\mathrm{Bu}$ yaş grubunda daha iyi bir risk skorlama sistemi için toplum tabanlı validasyon çalışmalarına ihtiyaç vardır.

Anahtar sözcükler: Kalp cerrahisi , mortalite, 80 yaş ve üzeri, risk skorları.

Received: January 06, 2021 Accepted: March 22, 2021 Published online: April 26, 2021

Correspondence: Murat Baștopçu, MD. Dr. Siyami Ersek Göğüs Kalp ve Damar Cerrahisi Eğitim ve Araștırma Hastanesi, Kalp ve Damar Cerrahisi Kliniği, 34668 Üsküdar, İstanbul, Türkiye. Tel: +90 216 - 5424444 e-mail: muratbastop@gmail.com 
With consistently improving life expectancy over the decades, an increasing number of octogenarians require cardiac surgery. These patients are likely to present with many comorbidities and face higher rates of morbidity and mortality after cardiac operations than patients under the age of $80 .{ }^{[1]}$ Although available risk scoring systems provide a satisfactory mortality prediction for patients undergoing cardiac surgery, their performance is debatable for the octogenarian population. ${ }^{[2]}$

The Society of Thoracic Surgeons (STS) score is extensively used for predicting early and late mortality after cardiac operations. It is also advantageous in providing information on other postoperative outcomes including length of stay, stroke, and reoperations. Although it is valuable for isolated coronary and valve surgery, one of the shortcomings of the STS score is that it cannot be applied to ablation surgery or multiple valve operations. ${ }^{[3]}$ The logistic European System for Cardiac Operative Risk Evaluation (EuroSCORE) II has been used for a long time and, compared to the STS score, is applicable over a wider variety of cardiac operations. ${ }^{[4]}$ On the other hand, the EuroSCORE II has been modeled with fewer patients than the STS score and the incorporated variables used to predict mortality are not as extensive. ${ }^{[5]}$ For elderly cardiac surgery patients, the logistic EuroSCORE II tends to overestimate mortality, while the STS score gives lower than observed estimates. ${ }^{[6]}$

The complexity of the octogenarian group may affect the predictive ability of the scoring systems. Despite the reproduced validity of mortality and morbidity prediction for other age groups, many reports have been published debating their application in octogenarians. Observed mortality among octogenarians is often higher than predicted by the risk scoring systems, while still acceptable when considered in the light of the expected survival of the patients in this age group. ${ }^{[7]}$ Thus, calculating the operative risk of octogenarians with the present risk scoring systems raises the one-size-fits-all concern for surgeons.

In the present study, we attempted to discuss an important question about the validity of EuroSCORE II and STS for mortality in octogenarians undergoing cardiac surgery. We, therefore, aimed to investigate the predictive value of STS and EuroSCORE II scores for mortality in octogenarian cardiac surgery patients based on their compatibility with observed mortality.

\section{PATIENTS AND METHODS}

This single-center, retrospective study was conducted at Dr. Siyami Ersek Thoracic and Cardiovascular Surgery Training and Research Hospital, Department of Cardiovascular Surgery between January 2016 and December 2019. All elective and urgent cardiac operations throughout the study period were analyzed. There were 7,506 cardiac operations in our institution and 116 of them were performed in octogenarians ( 73 males, 43 females; mean age: $82.9 \pm 3.1$ years; range, 80 to 97 years) that were included in the study. Prior to surgery, a written informed consent was obtained from each patient. The study protocol was approved by the Institutional Review Board of Dr. Siyami Ersek Thoracic and Cardiovascular Surgery Training and Research Hospital (16.07.2020/No.28001928-604.01.01). The study was conducted in accordance with the principles of the Declaration of Helsinki.

Patients' demographics, operative data including aortic clamp and cardiopulmonary bypass times were recorded. The STS and EuroSCORE II scores were calculated for each patient using the online calculators at riskcalc.sts.org and www.euroscore.org. Preoperative creatinine clearance was calculated according to the Chronic Kidney Disease Epidemiology Collaboration method. An ejection fraction of $>50 \%$ was defined as normal, between $30 \%$ and $50 \%$ as moderate, and $<30 \%$ as low. Pulmonary artery systolic pressures were recorded as moderate for 31 to $55 \mathrm{mmHg}$ and severe for $>55 \mathrm{mmHg}$. For postoperative endpoints, STS definitions were used. Mortality was as all death events occurring within 30 days after surgery and as deaths in the hospital where the operation took place even after 30 days. Postoperative events including stroke, dialysis requirement, and reoperation were recorded. Stroke was defined as acute hemorrhage or infarction of the brain, spinal cord, or the retina lasting for $>24 \mathrm{~h}$. Length of hospital and intensive care unit stay was recorded in days. Postoperative infection included infections at any site including pneumonia, superficial wound infections, deep sternal wound infections, and septicemia. Patients with and without mortality were compared for their demographic and operative factors. Predicted and observed mortalities were compared for both scoring systems.

\section{Statistical analysis}

Statistical analysis was performed using the Number Cruncher Statistical System (NCSS 2007) version 1 software (NCSS LLC, Kaysville, UT, USA). Normality was tested with the Shapiro-Wilk test. Descriptive data 
Table 1. Demographic and operative characteristics of octogenarian patients $(n=116)$

\begin{tabular}{|c|c|c|c|c|c|}
\hline & $\mathrm{n}$ & $\%$ & Mean \pm SD & Median & IQR \\
\hline Age (year) & & & $82.9 \pm 3.1$ & & \\
\hline \multicolumn{6}{|l|}{ Sex } \\
\hline Male & 73 & 62.9 & & & \\
\hline Female & 43 & 37.1 & & & \\
\hline Body mass index $\left(\mathrm{kg} / \mathrm{m}^{2}\right)$ & & & $28.5 \pm 4.7$ & & \\
\hline \multicolumn{6}{|l|}{ Body mass index $(\mathrm{n}=95)$} \\
\hline Normal & 27 & 28.4 & & & \\
\hline Overweight & 32 & 33.7 & & & \\
\hline Obese class I & 24 & 25.3 & & & \\
\hline Obese class II & 12 & 12.6 & & & \\
\hline \multicolumn{6}{|l|}{ Operation } \\
\hline Elective & 89 & 76.7 & & & \\
\hline Urgent & 27 & 23.3 & & & \\
\hline \multicolumn{6}{|l|}{ Operation type } \\
\hline CABG & 65 & 56.0 & & & \\
\hline Mitral valve surgery & 20 & 17.2 & & & \\
\hline Aortic valve surgery & 10 & 8.6 & & & \\
\hline Aortic valve surgery $+\mathrm{CABG}$ & 16 & 13.8 & & & \\
\hline Mitral valve surgery $+\mathrm{CABG}$ & 5 & 4.3 & & & \\
\hline Diabetes mellitus & 54 & 46.6 & & & \\
\hline Hypertension & 52 & 44.8 & & & \\
\hline Preoperative pulmonary artery pressure & & & $30.9 \pm 13.1$ & & \\
\hline \multicolumn{6}{|l|}{ Pulmonary hypertension } \\
\hline Normal & 68 & 58.6 & & & \\
\hline Moderate & 42 & 36.2 & & & \\
\hline Severe & 6 & 5.2 & & & \\
\hline Cardiopulmonary bypass time & & & $118.6 \pm 37.4$ & & \\
\hline Aortic cross clamp time & & & & 85 & $64-118$ \\
\hline Creatinine clearance & & & $62.3 \pm 17.7$ & & \\
\hline Preoperative ejection fraction & & & $51.6 \pm 9.7$ & & \\
\hline \multicolumn{6}{|l|}{ Preoperative ejection fraction $(\mathrm{n}=110)$} \\
\hline Normal & 63 & 57.3 & & & \\
\hline Moderate & 40 & 36.4 & & & \\
\hline Low & 7 & 6.4 & & & \\
\hline Peripheral arterial disease & 2 & 1.8 & & & \\
\hline History of stroke & 3 & 2.6 & & & \\
\hline Postoperative stroke & 7 & 6.0 & & & \\
\hline Postoperative renal failure & 16 & 13.8 & & & \\
\hline Postoperative infection & 12 & 10.3 & & & \\
\hline Reoperation & 30 & 25.9 & & & \\
\hline Mechanical ventilation time (days) & & & & 1 & $1-2$ \\
\hline Length of stay in the intensive care & & & & 2 & $1-3$ \\
\hline Total length of stay & & & & 7 & $6-12$ \\
\hline EuroSCORE II & & & $5.2 \pm 5.4$ & & \\
\hline Society of thoracic surgeons & & & $3.7 \pm 11.1$ & & \\
\hline Mortality & 32 & 27.6 & & & \\
\hline
\end{tabular}

SD: Standard deviation; IQR: Interquartile range; CABG: Coronary artery bypass grafting. 
were expressed in mean \pm standard deviation (SD), median (min-max) or number and frequency. Groups were compared with the Student's t-test for variables with normal distribution, Mann-Whitney U test for variables without normal distribution, and Pearson's chi-square test, Fisher's exact test, and Fisher-FreemanHalton exact test, when appropriate for categorical variables. The receiver operating characteristic (ROC) curves were constructed for the two scoring systems and their area under the curve (AUC) values were compared using the DeLong's method. A $p$ value of $<0.05$ was considered statistically significant.

\section{RESULTS}

Baseline demographic and operative characteristics of the patients are shown in Table 1.

Table 2. Comparison of patient characteristics according to mortality

\begin{tabular}{|c|c|c|c|c|c|c|c|c|c|c|c|}
\hline & & & No mortality & $n=84)$ & & & & Mortality ( & $=32)$ & & \\
\hline & $\mathrm{n}$ & $\%$ & Mean \pm SD & Median & IQR & $\mathrm{n}$ & $\%$ & Mean \pm SD & Median & IQR & $p$ \\
\hline Age (year) & & & & $82.4 \pm 2.5$ & & & & $84.1 \pm 4.1$ & & & 0.030 \\
\hline Sex & & & & & & & & & & & \\
\hline Female & 30 & 35.7 & & & & 13 & 40.6 & & & & 0.625 \\
\hline Body mass index $\left(\mathrm{kg} / \mathrm{m}^{2}\right)$ & & & $28.3 \pm 4.6$ & & & & & $29.4 \pm 4.5$ & & & 0.351 \\
\hline Body mass index (n=95) & & & & & & & & & & & 0.836 \\
\hline Normal & 24 & 32.0 & & & & 5 & 25.0 & & & & \\
\hline Overweight & 25 & 33.3 & & & & 5 & 25.0 & & & & \\
\hline Obese class I & 17 & 22.7 & & & & 7 & 35.0 & & & & \\
\hline Obese class II & 9 & 12.0 & & & & 3 & 15.0 & & & & \\
\hline Operation & & & & & & & & & & & 0.006 \\
\hline Elective & 70 & 94.6 & & & & 19 & 59.4 & & & & \\
\hline Urgent & 14 & 16.7 & & & & 13 & 40.6 & & & & \\
\hline Operation type & & & & & & & & & & & 0.023 \\
\hline CABG & 53 & 63.1 & & & & 12 & 37.5 & & & & \\
\hline Mitral valve surgery & 14 & 16.7 & & & & 6 & 18.8 & & & & \\
\hline Aortic valve surgery & 4 & 4.8 & & & & 6 & 18.8 & & & & \\
\hline Aortic valve surgery $+\mathrm{CABG}$ & 11 & 13.1 & & & & 5 & 15.7 & & & & \\
\hline Mitral valve surgery + CABG & 2 & 2.4 & & & & 3 & 9.4 & & & & \\
\hline Diabetes mellitus & 33 & 39.3 & & & & 21 & 65.7 & & & & 0.011 \\
\hline Hypertension & 34 & 40.5 & & & & 18 & 56.3 & & & & 0.127 \\
\hline Preoperative pulmonary artery pressure & & & $30.0 \pm 12.3$ & & & & & $33.4 \pm 15.0$ & & & 0.209 \\
\hline Pulmonary hypertension & & & & & & & & & & & 0.070 \\
\hline Normal & 49 & 58.3 & & & & 19 & 59.4 & & & & \\
\hline Moderate & 33 & 39.3 & & & & 9 & 28.1 & & & & \\
\hline Severe & 2 & 2.4 & & & & 4 & 12.5 & & & & \\
\hline Cardiopulmonary bypass time & & & $115.7 \pm 35.8$ & & & & & $126.2 \pm 40.9$ & & & 0.176 \\
\hline Aortic cross clamp time & & & & 81 & $58-118$ & & & & 85 & $75-126$ & 0.172 \\
\hline Creatinine clearance & & & $65.3 \pm 15.4$ & & & & & $54.4 \pm 20.9$ & & & 0.010 \\
\hline Preoperative ejection fraction & & & $52.3 \pm 9.5$ & & & & & $49.3 \pm 10.0$ & & & 0.152 \\
\hline Preoperative ejection fraction $(n=110)$ & & & & & & & & & & & 0.396 \\
\hline Normal & 50 & 59.5 & & & & 13 & 46.4 & & & & \\
\hline Moderate & 27 & 32.1 & & & & 13 & 46.4 & & & & \\
\hline Low & 5 & 59.5 & & & & 2 & 6.3 & & & & \\
\hline Peripheral arterial disease & 2 & 2.4 & & & & 0 & 0 & & & & 0.999 \\
\hline History of stroke & 3 & 3.6 & & & & 0 & 0 & & & & 0.565 \\
\hline Postoperative stroke & 4 & 4.8 & & & & 3 & 9.4 & & & & 0.377 \\
\hline Postoperative renal failure & 4 & 4.8 & & & & 12 & 37.5 & & & & $<0.001$ \\
\hline Postoperative infection & 5 & 6.0 & & & & 7 & 21.9 & & & & 0.013 \\
\hline Reoperation & 13 & 15.5 & & & & 17 & 53.1 & & & & $<0.001$ \\
\hline Mechanical ventilation time (days) & 1 & 1.1 & & & & 2 & 1.5 & & & & $<0.001$ \\
\hline Length of stay in the intensive care & 1 & 1.2 & & & & 2 & 1.5 & & & & 0.006 \\
\hline Total length of stay & & & & 7.5 & $7-12$ & & & & 4 & $1-10.5$ & $<0.001$ \\
\hline
\end{tabular}


Table 3. STS and EuroSCORE II according to mortality

\begin{tabular}{|c|c|c|c|c|c|}
\hline & & & \multirow{2}{*}{$\frac{\text { No mortality }(\mathrm{n}=84)}{\text { Mean } \pm \text { SD }}$} & \multirow{2}{*}{$\frac{\text { Mortality }(\mathrm{n}=32)}{\text { Mean } \pm \text { SD }}$} & \multirow[b]{2}{*}{$p$} \\
\hline & & & & & \\
\hline \multirow{6}{*}{ 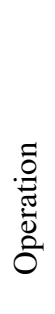 } & \multirow{2}{*}{ All patients $(\mathrm{n}=116)$} & STS & $3.0 \pm 8.7$ & $5.4 \pm 15.8$ & 0.423 \\
\hline & & EuroSCORE II & $4.1 \pm 4.0$ & $8.1 \pm 7.4$ & 0.006 \\
\hline & \multirow{2}{*}{ Elective $(\mathrm{n}=89)$} & STS & $3.2 \pm 9.5$ & $7.7 \pm 20.3$ & 0.165 \\
\hline & & EuroSCORE II & $3.7 \pm 3.9$ & $7.2 \pm 7.3$ & 0.006 \\
\hline & \multirow{2}{*}{ Urgent $(n=27)$} & STS & $2.1 \pm 0.9$ & $2.0 \pm 1.0$ & 0.869 \\
\hline & & EuroSCORE II & $6.3 \pm 4.2$ & $9.5 \pm 7.5$ & 0.181 \\
\hline \multirow{10}{*}{ 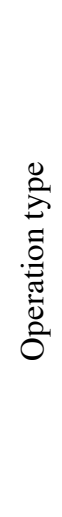 } & \multirow{2}{*}{ CABG $(n=65)$} & STS & $1.8 \pm 0.9$ & $1.8 \pm 0.7$ & 0.947 \\
\hline & & EuroSCORE II & $4.2 \pm 4.3$ & $6 \pm 6.3$ & 0.231 \\
\hline & \multirow{2}{*}{ Mitral valve surgery $(n=20)$} & STS & $7.6 \pm 21.1$ & $16.6 \pm 35.6$ & 0.489 \\
\hline & & EuroSCORE II & $2.5 \pm 1.0$ & $11.5 \pm 11.2$ & 0.006 \\
\hline & \multirow{2}{*}{ Aortic valve surgery $(n=10)$} & STS & $2.6 \pm 1.3$ & $2.5 \pm 1.0$ & 0.848 \\
\hline & & EuroSCORE II & $5.2 \pm 3.9$ & $11.2 \pm 8.6$ & 0.233 \\
\hline & \multirow{2}{*}{ Aortic valve surgery + CABG $(n=16)$} & STS & $3.3 \pm 1.7$ & $2.3 \pm 1.3$ & 0.260 \\
\hline & & EuroSCORE II & $4.7 \pm 3.9$ & $6.1 \pm 2.9$ & 0.494 \\
\hline & \multirow{2}{*}{ Mitral valve surgery + CABG $(n=5)$} & STS & $3.0 \pm 2.0$ & $8.7 \pm 12.5$ & 0.585 \\
\hline & & EuroSCORE II & $8.3 \pm 9.4$ & $7.1 \pm 2.5$ & 0.832 \\
\hline
\end{tabular}

SD: Standard deviation; STS: Society of Thoracic Surgeons; EuroSCORE II: European System for Cardiac Operative Risk Evaluation II; CABG: Coronary artery bypass grafting.

The mean STS score of all octogenarian patients was 3.7 \pm 11.1 and the mean EuroSCORE II was 5.2 \pm 5.4 . The most frequent type of operation was isolated coronary artery bypass grafting (CABG) in $56.0 \%$ of the patients, while $25.8 \%$ of the patients required isolated valve surgery and $18.1 \%$ required combined valve + CABG surgery.

Octogenarian patients with mortality had more frequently diabetes mellitus, lower creatinine clearance, postoperative dialysis requirement, and prolonged intubation. Mortality varied with the type of operation performed and was significantly higher $(\mathrm{p}=0.023)$ for CABG + mitral valve surgery and aortic valve surgery. Urgent operations had a higher mortality than elective operations $(40.6 \%$ vs. $16.7 \%$, respectively; $\mathrm{p}=0.006)$ (Table 2).

The patients with and without mortality were compared for their STS and EuroSCORE II calculations. For any operation type, the mean EuroSCORE II was significantly higher $(8.1 \pm 7.4 \mathrm{vs} .4 .1 \pm 4.0$, respectively; $\mathrm{p}=0.006)$ in the patients with mortality. For elective operations, the mean EuroSCORE II was higher in cases with mortality $(7.2 \pm 7.3 v s .3 .7 \pm 3.9$, respectively; $\mathrm{p}=0.006$ ); however, for urgent cases, there was no significant difference between the scores. In addition, the STS scores did not significantly differ in terms of mortality among all patients, in elective cases, or urgent cases (Table 3).

Despite the finding that EuroSCORE II was better than the STS score in mortality prediction for our octogenarian patient population, the prediction was markedly lower than observed. The observed mortality for all patients, elective and urgent cases were $27.6 \%, 21.3 \%$, and $48.1 \%$, respectively while the predicted mortality rates ranged between 2 and $9 \%$ with EuroSCORE II and STS scores (Table 4). The CABG was the most frequently performed operation in study group (56\%) and observed mortality rate was $18.5 \%$ versus a predicted mortality rate of $6 \pm 6.3 \%$ for EuroSCORE II and $1.8 \pm 0.7 \%$ STS scores.

To compare the discriminatory ability of the two scoring systems for mortality, the ROC curves were constructed (Figure 1). The AUC value for all operations, elective operations, and urgent operations were compared separately. The EuroSCORE II had 
Table 4. Observed and predicted mortality rates

\begin{tabular}{|c|c|c|c|c|}
\hline & & & $\%$ & Mean \pm SD \\
\hline & & STS & & $5.40 \pm 15.8$ \\
\hline & atients $(n=116)$ & EuroSCORE II & & $8.1 \pm 7.34$ \\
\hline & & Observed & 27.6 & \\
\hline ๘ี & Elective $(\mathrm{n}=89)$ & STS & & $7.7 \pm 20.3$ \\
\hline 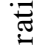 & & EuroSCORE II & & $7.2 \pm 7.3$ \\
\hline ठै & & Observed & 21.3 & \\
\hline 0 & Urgent $(n=27)$ & STS & & $2.0 \pm 1.0$ \\
\hline 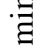 & & EuroSCORE II & & $9.5 \pm 7.5$ \\
\hline$F$ & & Observed & 48.1 & \\
\hline & CABG $(n=65)$ & STS & & $1.8 \pm 0.8$ \\
\hline & & EuroSCORE II & & $4.5 \pm 4.8$ \\
\hline & & & 18.5 & \\
\hline & Mitral valve surgery $(n=20)$ & STS & & $6.3 \pm 17.6$ \\
\hline & & EuroSCORE II & & $5.2 \pm 7.2$ \\
\hline$\approx$ & & Observed & 30.0 & \\
\hline 之 & Aortic valve surgery $(n=10)$ & STS & & $2.5 \pm 1.0$ \\
\hline : & & EuroSCORE II & & $9.4 \pm 7.7$ \\
\hline ڤ్ర & & Observed & 60.0 & \\
\hline & Aortic valve + CABG $(n=16)$ & STS & & $3.0 \pm 1.7$ \\
\hline & & EuroSCORE II & & $5.3 \pm 3.6$ \\
\hline & & Observed & 33.3 & \\
\hline & Mitral valve + CABG $(n=5)$ & STS & & $6.4 \pm 9.4$ \\
\hline & & EuroSCORE II & & $7.5 \pm 5.1$ \\
\hline & & & 60.0 & \\
\hline
\end{tabular}

SD: Standard deviation; STS: Society of thoracic surgeons; EuroSCORE II: European System for Cardiac Operative Risk Evaluation II; CABG: Coronary artery bypass grafting.

a higher AUC for all operations (0.754 vs. 0.537, respectively; $p=0.003$ ). Although the EuroSCORE II had a higher AUC for urgent and elective operations as well, the differences over AUC of STS scores did not reach statistical significance (Table 5).

\section{DISCUSSION}

In our retrospective cohort of octogenarians, the EuroSCORE II performed better than STS in predicting mortality. For all cardiac operations, the EuroSCORE II could predict mortality with better discrimination, while the STS score could not provide a significant mortality prediction. Neither scoring system could significantly predict mortality in urgent cases. Based on our results, we can speculate that the EuroSCORE II is better than STS score for risk prediction in this age group.

With the ongoing effort to improve and update risk prediction models to accommodate changing practices, the EuroSCORE model was revised in 2011 and the STS is recalibrated regularly. The two major scoring systems have their strengths and weaknesses for specific patient groups. With the aging population, more cardiac operations are performed in patients above 80 years of age, and both major risk scores have shortcomings for this age group. ${ }^{[8]}$ Elderly patients $>80$ years of age were underrepresented in the model for the EuroSCORE II study, and only 21 patients above the age of 90 were included. ${ }^{[4]}$ 


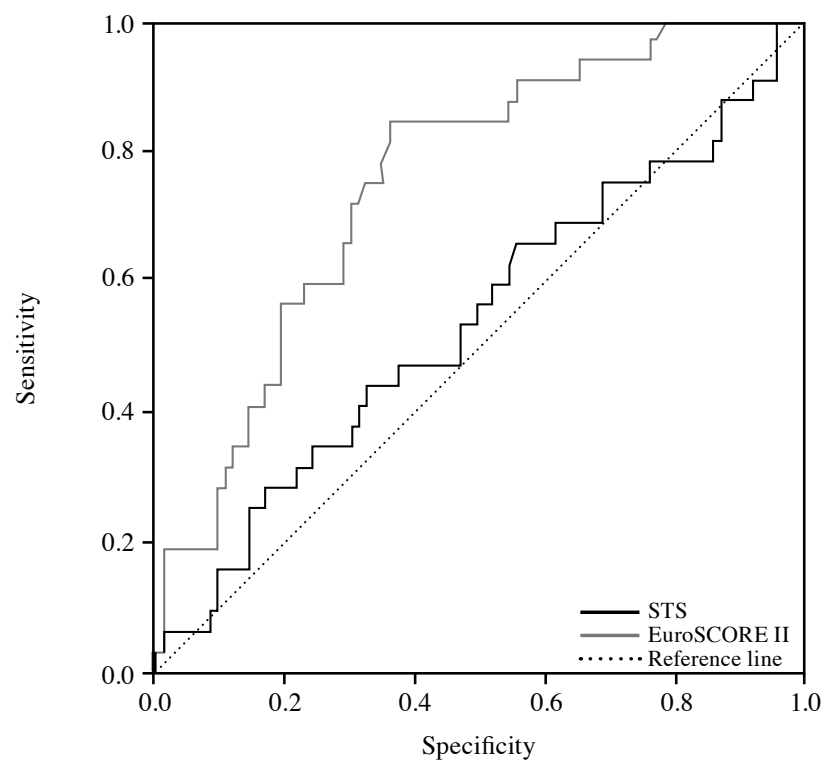

Figure 1. ROC curves for EuroSCORE II and STS score for mortality in all cardiac operations.

ROC: Receiver operating characteristic; STS: Society of Thoracic Surgeons; EuroSCORE II: European System for Cardiac Operative Risk Evaluation II.

Few studies validating the EuroSCORE and STS have focused on the aging population, and it is still unclear which one is more accurate in this setting. A study including octogenarians found an AUC of 0.745 for the EuroSCORE II and 0.694 for the STS for 30-day mortality, and another study including Greek cardiac surgery patients above the age of 60 years found the EuroSCORE to predict mortality with an AUC of $0.84 .{ }^{[9,10]}$ While these two studies show the EuroSCORE II to be a better tool for the elderly, the Frailty in Cardiac Surgery Study in patients aged above 65 years revealed the comprehensive assessment of frailty (CAF) score to perform better than both scores with an AUC of 0.700 , and the
STS score was better with an AUC of 0.748 than the EuroSCORE II with an AUC of 0.664. ${ }^{[11]}$ The EuroSCORE II performed relatively better than the STS score in our octogenarian patients; however, we lack the data on frailty scores to assess whether they outperform EuroSCORE II in this patient population. While frailty scores appear to be better for octogenarians, they have not been extensively validated as the major scoring systems. The lack of a universally validated risk scoring system with a satisfactory performance in this specific patient population brings about the necessity for a population study on octogenarians in cardiac surgery.

Our cohort was composed nearly half of combined operations and aortic surgeries. Moreover, $23.3 \%$ of all of operations on octogenarians were urgent operations with a higher associated mortality rate. Urgent interventions and combined surgery are more frequent in elderly cardiac patients than in younger patients. ${ }^{[12,13]}$ With $23.3 \%$ urgent operations and $18.1 \%$ combined valve and coronary surgery, our cohort reflects this trend. For combined operations, the EuroSCORE II tends to overestimate the risk, while it underestimates mortality for urgent operations. ${ }^{[5,14-16]}$ For combined operations, the STS is better than EuroSCORE II; ${ }^{[17,18]}$ however, it can nevertheless underestimate mortality in elderly. ${ }^{[19]}$ Mortality for our urgent operations in our patients $(48.1 \%)$ was almost twice as for elective operations $(21.3 \%)$. A higher estimate of mortality was given by the EuroSCORE II for patients undergoing urgent operations. Nevertheless, the observed mortality was higher than the expected percentage.

For our isolated valve surgery patients, the EuroSCORE II, but not STS, was able to predict mortality. However, both scoring systems failed to provide significant predictions for other types of surgery. For urgent operations, neither EuroSCORE II nor STS helped predict mortality for our patients.

Table 5. ROC analyses for EuroSCORE II and STS score for mortality in octogenarian patients

\begin{tabular}{|c|c|c|c|c|c|c|}
\hline & & & AUC & $95 \% \mathrm{CI}$ & $P$ for $\mathrm{AUC}>0.5$ & $\begin{array}{l}P \text { for difference } \\
\text { between curves }\end{array}$ \\
\hline \multirow[t]{2}{*}{ All operations } & & STS & 0.537 & $0.422-0.631$ & 0.554 & \multirow{2}{*}{0.003} \\
\hline & & EuroSCORE II & 0.754 & $0.665-0.829$ & $<0.001$ & \\
\hline \multirow{4}{*}{ 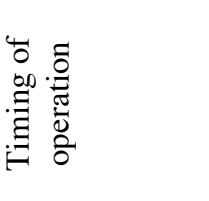 } & Elective & STS & 0.584 & $0.443-0.726$ & 0.243 & \multirow{2}{*}{0.692} \\
\hline & & EuroSCORE II & 0.761 & $0.644-0.877$ & $<0.001$ & \\
\hline & Urgent & STS & 0.524 & $0.281-0.766$ & 0.848 & \multirow{2}{*}{0.058} \\
\hline & & EuroSCORE II & 0.615 & $0.392-0.838$ & 0.310 & \\
\hline
\end{tabular}

ROC: Receiver operating characteristic; EuroSCORE II: European System for Cardiac Operative Risk Evaluation II; STS: Society of thoracic surgeons; AUC: Area under the curve; CI: Confidence interval. 
Although EuroSCORE II performed better overall, the limitations of these scores in our center to allow for clinical decision making in octogenarians stresses the need for a better risk model for these patients. Frailty assessment emerges as an important factor for elderly surgery candidates. Poor mobility is included in the EuroSCORE II; however, both major risk scores lack the many factors considered in frailty. ${ }^{[20]}$ Among the various criteria used for frailty tests, gait speed emerges as a single factor that is valuable in mortality prediction ${ }^{[21]}$ and the STS has incorporated gait speed into its risk factors. Incorporation of other factors of frailty could improve the model for the elderly age group.

As a tertiary referral center, the complexity and morbidity of our patient population is expected to be higher in all age groups. However, the EuroSCORE II and STS scores in our octogenarian patients did not reflect their actual complexity and associated morbidity. The predictive mortalities were much lower than the observed rates for each operation type. This finding indicates that the risk factor impact of the studied population while developing the scoring systems differs from the risk factor impact in the applied population. Such a difference between the predicted and observed mortality should give a reason to look for factors in the major scoring systems with impacts inconsistent in octogenarians and for other factors that perform better in this age group with the aim of a prediction system that better fits this specific population.

The main limitations of our study are its singlecenter design, the limited sample size, and its retrospective design. Therefore, the results may not be directly comparable to those from other institutions where demographics and surgical practices vary. Due to the limited number of octogenarian patients, subgroup analysis with individual operation types could not be performed. In addition, our study only analyzed mortality, but not the other endpoints predicted by the STS score. Our definition for postoperative infections was also different from the STS score model's definition which included only deep sternal wound infections. Further studies designed to compare the observed and predicted morbidities are necessary to validate the STS score in this respect.

In conclusion, despite the finding that the EuroSCORE II performed better than the STS score in mortality prediction for octogenarians undergoing cardiac operations, the observed mortality in our study was markedly higher than the predicted values. Instead of using a one-size-fits-all risk calculation in a complex patient group such as octogenarians, a more detailed risk scoring system for a better predictive performance is needed.

\section{Declaration of conflicting interests}

The authors declared no conflicts of interest with respect to the authorship and/or publication of this article.

\section{Funding}

The authors received no financial support for the research and/or authorship of this article.

\section{REFERENCES}

1. Prêtre R, Turina MI.Cardiac valve surgery in the octogenarian. Heart 2000;83:116-21.

2. Pratesi A, Orso F, Ghiara C, Lo Forte A, Baroncini AC, Di Meo ML, et al. Cardiac surgery in the elderly: What goals of care? Monaldi Arch Chest Dis 2017;87:852.

3. O'Brian AM, Shahian DM, Filardo G, Ferraris VA, Haan CK, Rich JB, et al. The Society of Thoracic Surgeons 2008 cardiac surgery risk models: part 2--isolated valve surgery. Ann Thorac Surg 2009;88(1 Suppl):S23-42.

4. Nashef SA, Roques F, Sharples LD, Nilsson J, Smith C, Goldstone AR, et al. EuroSCORE II. Eur J Cardiothorac Surg 2012;41:734-44.

5. Guida P, Mastro F, Scrascia G, Whitlock R, Paparella D. Performance of the European System for Cardiac Operative Risk Evaluation II: A meta-analysis of 22 studies involving 145,592 cardiac surgery procedures. J Thorac Cardiovasc Surg 2014;148:3049-57.e1.

6. Sepehri A, Beggs T, Hassan A, Rigatto C, Shaw-Daigle C, Tangri N, et al. The impact of frailty on outcomes after cardiac surgery: A systematic review. J Thorac Cardiovasc Surg 2014;148:3110-7.

7. Demir A, Pepeşengül E, Aydınlı B, Tezcan B, Eke H, Taşoğlu $\dot{I}$, et al. Cardiac surgery and anesthesia in an elderly and very elderly patient population: a retrospective study. Turk Gogus Kalp Dama 2011;19:377-83.

8. Poullis M, Pullan M, Chalmers J, Mediratta N. The validity of the original EuroSCORE and EuroSCORE II in patients over the age of seventy. Interact Cardiovasc Thorac Surg 2015;20:172-7.

9. Ghanta RK, Shekar PS, McGurk S, Rosborough DM, Aranki SF. Nonelective cardiac surgery in the elderly: Is it justified? J Thorac Cardiovasc Surg 2010;140:103-9, 109.e1.

10. Stavridis G, Panaretos D, Kadda O, Panagiotakos DB. Validation of the EuroSCORE II in a Greek cardiac surgical population: A Prospective Study. Open Cardiovasc Med J 2017;11:94-101.

11. Bäck C, Hornum M, Olsen PS, Møller CH. 30-day mortality in frail patients undergoing cardiac surgery: The results of the frailty in cardiac surgery (FICS) copenhagen study. Scand Cardiovasc J 2019;53:348-54.

12. Drury NE, Nashef SA. Outcomes of cardiac surgery in the elderly. Expert Rev Cardiovasc Ther 2006;4:535-42.

13. Erkanlı K, Aksu T, Aydın Ü, Şen O, Kutluk E, Kaya M, et al. Seksen yaş ve üzeri hastalarda koroner arter bypass 
cerrahisine ek olarak uygulanan prosedürler operasyonun riskini arttırır mı? Haseki Tıp Bülteni 2014; 52:14-8.

14. Borde D, Gandhe U, Hargave N, Pandey K, Khullar V. The application of European system for cardiac operative risk evaluation II (EuroSCORE II) and Society of Thoracic Surgeons (STS) risk-score for risk stratification in Indian patients undergoing cardiac surgery. Ann Card Anaesth 2013;16:163-6.

15. Speziale G, Nasso G, Barattoni MC, Bonifazi R, Esposito $\mathrm{G}$, Coppola R, et al. Operative and middle-term results of cardiac surgery in nonagenarians: A bridge toward routine practice. Circulation 2010;121:208-13.

16. Easo J, Hölzl PP, Horst M, Dikov V, Litmathe J, Dapunt O. Cardiac surgery in nonagenarians: Pushing the boundary one further decade. Arch Gerontol Geriatr 2011;53:229-32.
17. Ad N, Holmes SD, Patel J, Pritchard G, Shuman DJ, Halpin L. Comparison of EuroSCORE II, Original EuroSCORE, and The Society of Thoracic Surgeons Risk score in cardiac surgery patients. Ann Thorac Surg 2016;102:573-9.

18. Rabbani MS, Qadir I, Ahmed Y, Gul M, Sharif H. Heart valve surgery: EuroSCORE vs. EuroSCORE II vs. Society of Thoracic Surgeons score. Heart Int 2014;9:53-8.

19. Davis JP, LaPar DJ, Crosby IK, Kern JA, Lau CL, Kron IL, et al. Nonagenarians undergoing cardiac surgery. J Card Surg 2014;29:600-4.

20. Yaffee DW, Williams MR. Cardiovascular surgery in the elderly. Semin Thorac Cardiovasc Surg 2016;28:741-7.

21. Afilalo J, Kim S, O’Brien S, Brennan JM, Edwards FH, Mack MJ, et al. Gait speed and operative mortality in older adults following cardiac surgery. JAMA Cardiol 2016;1:314-21. 